() О. О. Палюх, к.т.н., доцент, КП। ім. Ігоря Сікорського, Київ, Україна

\title{
ЕКСПЕРИМЕНТАЛЬНЕ ВИЗНАЧЕННЯ ВПЛИВУ ПАЛІТУРНИХ КЛЕЇВ НА УТВОРЕННЯ ПРИРОДНИХ КУТІВ РОЗКРИВАННЯ КНИЖКОВИХ БЛОКІВ
}

Виготовлення книжкової продукції інтенсивного та довготривалого використання, забезпечення міцності і довговічності клейових 3'єднань корінців книжкових блоків, зшитих нитками, створює підстави дотримання основних показників експлуатаційної надійності всього книжкового видання. Аналіз проведених досліджень утворення максимального природного кута розкривання книжкових блоків, без прикладання додаткових зусиль, направлених на деформацію корінцевої частини, виявив композиції деяких видів клеїв, що забезпечують максимальну міцність скріплення корінців і одночасно високу еластичність, що сприяє максимальному куту розкривання блоків зшитих нитками і має прикладне значення при моделюванні макетів книг, виборі технології їх виготовлення та застосуванні сучасних палітурних матеріалів.

Ключові слова: книжкові блоки; кути розкривання; кути відхилення; міцність скріплення; палітурні клеї; руйнування блоків.

\section{Постановка проблеми}

Завданням експериментального дослідження міцності та пластичності скріплення корінцевої частини книжкових блоків, зшитих нитками є визначення цифрових показників природних кутів розкривання блоків, які утворюються при розкриванні блоків без додаткових зусиль, направлених на деформацію корінцевої частини з метою отримання кутів розкривання наближених до $180^{\circ}$.

На підставі отриманих показників застосування деяких сучасних палітурних клеїв для скріплення корінців блоків, що впливають на збільшення міцності з'єднання та одночасну високу еластичність, створити практичні рекомендації можливих варіантів поєднання сортів та маси паперів, із яких виготовлені зошити в блоках, та композицій клеїв для корінцевої промазки.

\section{Аналіз попередніх} досліджень

Відомо, що книжкові видання, у яких блоки зшиті нитками, умовно можливо розділити на деякі групи, які будуть враховувати імовірне коло споживачів, а відповідно і прогнозовані експлуатаційні

(c) $2018 \mathrm{p}$. 
навантаження. До таких груп книжкових видань можна віднести дитячу літературу, довідкову, вузівську, технічну, шкільні підручники, словники, літературу з поліпшеними показниками матеріалів, подарункову, виготовлену із ексклюзивних складових, завдяки яким відтворюються складні високохудожні дизайнерські макети [1].

Відповідно, визначаючи умовну градацію видань при технологічному виготовленні, в першу чергу враховуються умови експлуатації книг: періодичне їх використання та зберігання в сприятливих статичних обставинах без впливу негативних факторів або інтенсивне застосування з додатковим експлуатаційним навантаженням за рахунок постійного транспортування та читання в різних умовах.

Для врахування особливостей технологічного виготовлення книжкової продукції необхідно враховувати основні види руйнувань книги, що виникають під час довготривалого їх використання [2]. Одним із таких важливих джерел накопичення інформації $€$ відомі потужні бібліотеки, які, через інтенсивність залучення книжкового фонду, змушені здійснювати відновлювальні технологічні операції найбільш зношених книжок для продовження їх читацької життєдіяльності.

Бібліотеки Німеччини виокремили основні види руйнувань книжкової продукції, які за відсотками до основної маси книг у бібліотечних фондах можливо розташувати у певній послідовності (табл. 1).

На гістограмі рис. 1 відтворена послідовність видів руйнувань книжкової продукції та їх відсоткова пропорційність.

Відомі дослідження книжкової продукції, у якої корінець блоку скріплений клейовим незшивним з'єднанням. Це дослідження впли-

Таблиця 1

Основні види руйнувань книжкової продукції

\begin{tabular}{|c|l|}
\hline № & \multicolumn{1}{|c|}{ Основні види експлуатаційних руйнувань книжкової продукції } \\
\hline 1 & руйнування форзаців по фальцю \\
\hline 2 & відрив форзаців від зошитів блоку \\
\hline 3 & $\begin{array}{l}\text { розрив по фальцю першого аркуша і відділення його разом із фор- } \\
\text { зацем і стороною палітурки від блоку }\end{array}$ \\
\hline 4 & розкол корінця блоку \\
\hline 5 & випадання аркушів книжкового блоку \\
\hline 6 & руйнування зв'язку палітурки з блоком \\
\hline 7 & відрив клапанів корінцевого матеріалу від палітурки \\
\hline 8 & випадання аркушів або зошитів через обрив ниток \\
\hline 9 & відрив корінцевого матеріалу від корінця блоку \\
\hline 10 & розшарування аркушів блоку при розкритті через ї склеювання \\
\hline 11 & розкол корінця блоку з руйнуванням корінцевого матеріалу \\
\hline 12 & руйнування корінцевого матеріалу і форзацу по фальцю \\
\hline
\end{tabular}


ву навантаження, якому піддається клейове з'єднання при читанні книги на якість розкриття видань незшивного клейового скріплення (НКC), дослідження факторів впливу на кути розкривання книжкових блоків, дослідження математичних моделей напруженодеформованого стану клейового з'єднання книжкового блоку, дослідження технології окантування корінців книжкових блоків при НКС та ін.

Вивченню особливостей поліграфічних матеріалів, дослідженню палітурних клеїв [3-6], умов їх використання у технологічних процесах з виготовлення книжкових блоків [7, 8] скріплених клейовим з'єднанням [9] присвячені роботи українських та іноземних вчених: Лазаренка Е. Т., Гавенко С. Ф., Петріашвілі Г. Мартинюк М. С., Розума О. Ф., Величко О. М., Кулик Л. Й., Clark T., Liebau D., Heinze I., Engeler H., Furler A., Sendor M. тощо. Peзультати досліджень українських та іноземних вчених частково застосовані в державних стандартах, що стосуються полігра- фічного виконання [10] та показників якості виготовлення книжкової продукції [11].

\section{Мета роботи}

Визначення впливу деяких сучасних видів палітурних клеїв, що використовуються для скріплення корінцевої частини книжкових блоків зшитих нитками, на утворення природних кутів розкривання блоків, які утворюються при розкриванні блоків без додаткових зусиль, направлених на деформацію корінцевої частини з метою отримання кутів розкривання наближених до $180^{\circ}$.

Перелік відібраних для дослідження зразків книжкової продукції відповідає основним конструкційним особливостям книжкових блоків 7БЦ, форматам видань від 125×200 мм до 210×285 мм та $300 \times 250$ мм, що є найбільш розповсюдженими в поліграфічному виконанні. Книжкові блоки виготовлені із основних видів паперів масою, що складає ши-

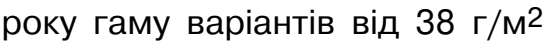
до 170 г/м².

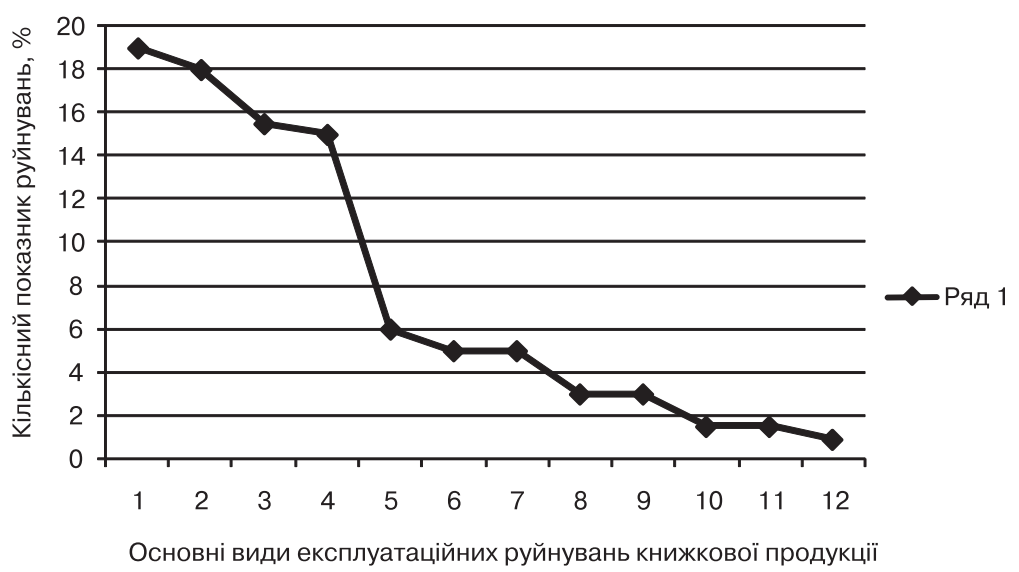

Рис. 1. Пропорційність видів руйнувань книжкової продукції після довготривалого використання 


\section{Результати проведених досліджень}

Аналізуючи процес розкривання книжкових блоків зшитих нитками, можливо звернути увагу на переріз корінцевої частини, що включає в себе частину від зони приклеювання блоку до форзацу, корінцеву частину блоку, частину обкладинки з відставою та розставами та другої частини зони приклеювання блоку до другого форзацу (нахзацу), що нагадує умовний шарнір (рис. 2), який змінює просторову конфігурацію при перегортанні сторінок книги і створює змінні за величиною пружні навантаження на зону приклеювання форзаців до блоку та на корінцеву частину блоку, що з часом призводять до руйнувань складових елементів книги у послідовності відображеній на рис. 1.

При використанні технології заклеювання корінця книжкових блоків, якість склеювання зшитих нитками зошитів буде визначати міцність з'єднання та довговічність використання книжкових видань. Природний кут розкривання книжкового блоку без до- кладання зусиль до деформації умовного шарніру (рис. 2) для отримання кута розкривання блоку в межах 150-180 значно менший за зручний для читання.

Фізико-механічні властивості матеріалів та дискретність зусиль, направлених на ефективне розкривання блоку, будуть супроводжуватися пружною, високо еластичною і пластичною видами деформації, що будуть змінювати розміри й форму видання та здійснювати його поступове руйнування.

При розкриванні книжкового блоку зшитого нитками, окантованого із заклеєним паперовою стрічкою корінцем (рис. 3), на утворення природних кутів розкривання блоку, в першу чергу, діє власна вага паперу зошитів, із яких складається блок, залежно від зони відкривання книжки, його маса, щільність, товщина, жорсткість, а також міцність клейового скріплення і окантовки корінця.

При послідовному перегортанні сторінок книжки, через зміну ї обсягів, змінюється навантаження на корінцеву частину блоку та

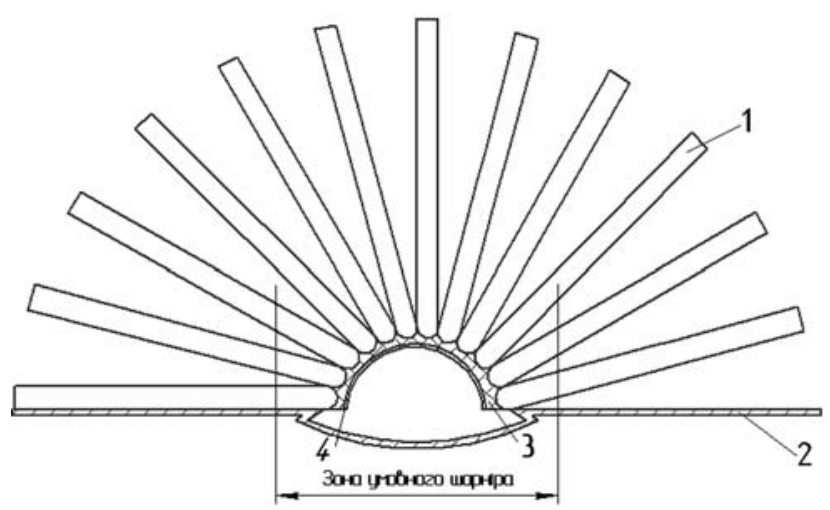

Рис. 2. Схема умовного перерізу книжкового блоку, зшитого нитками: 1 - зошит, 2 - обкладинка, 3 - шар клею, 4 - окантувальний матеріал 
корінцеву частину обкладинки (умовний шарнір, рис. 2), що збільшується в бік перегортання і зменшується в зворотний бік.

Зміна навантажень на корінець обкладинки, не дивлячись на товщину та матеріал відстави, особливо в блоках товщиною більше 20 мм, призводить до позиційного впливу на окремі ділянки корінця обкладинки, послідовні під час послідовного перегортання сторінок або в місцях, що залежать від зони дискретного розкривання блоку.

Такий вплив на корінцеву частину обкладинки відтворює процес поступового перегину в різних лінійних зонах матеріалу відстави, яка, з часом, втрачає пружність та цільність структури і перестає виконувати допоміжну функцію фіксатора переміщень для корінцевої частини книжкового блоку.

На рис. 4 показана схема утворення природних кутів розкривання книжкового блоку, що, у наведеному випадку, розкривається посередині, без додаткових зусиль, направлених на деформацію корінцевої частини з метою отримання кутів розкривання наближених до $180^{\circ}$.

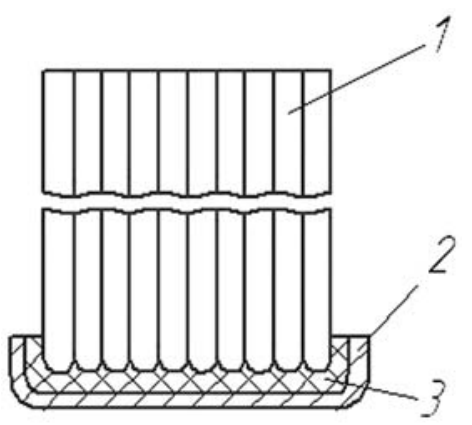

Рис. 3. 3'єднання корінця блоку:

1 - зошити, 2 - окантовка, 3 - шар клею
Відхилення кожного послідовного зошиту книжки при розкриванні блоку та утворення кутів нахилу зошитів залежить від критичного навантаження аркуша від власної ваги qкр (кгс/см), що визначається за формулою [3]:

$$
q_{k p}=\frac{E \cdot l \cdot K}{21^{3}},
$$

де E - модуль пружності аркуша паперу, кгс/см2; I - момент інерції аркуша на згин, см4; K безрозмірний коефіцієнт.

При послідовному відхиленні зошитів, при розкриванні блоку в правій і лівій частинах, сила згину першого зошита $F_{1}$ утворює кут нахилу $\varphi^{1}$, сила згину наступного зошиту $F_{2}-$ кут нахилу $\varphi^{2}$, $F_{i}$ - кут нахилу $\varphi^{i}$ :

$$
\begin{aligned}
& \vec{F}_{\Sigma_{i}}=\vec{F}_{1}+\vec{F}_{2}+\vec{F}_{3}+\ldots+\vec{F}_{i}, \\
& \vec{F}_{\Sigma_{j}}=\vec{F}_{5}+\vec{F}_{6}+\vec{F}_{7}+\ldots+\vec{F}_{j} .
\end{aligned}
$$

Для правої і лівої частини при повному розкриванні книжкового блоку під дією ваги паперу сторінок в зошитах утворюються природні кути розкривання блоку $\alpha^{1}$ і $\alpha^{2}$, що разом утворюють

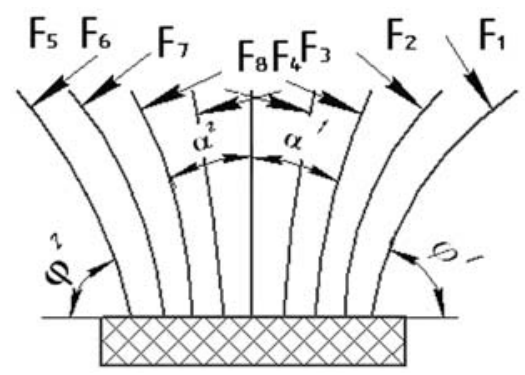

Рис. 4. Схема утворення природних кутів розкривання книжкових блоків, зшитих нитками, та кутів нахилу зошитів 
природний кут розкривання всього блоку $\alpha_{\Sigma}=\alpha^{1}+\alpha^{2}$.

Для тривалого збереження форми корінцевої частини при багаторазовому відкриванні книги у вигляді умовного півкруглого шарніра необхідно застосовувати для заклеювання фальців зошитів клеї, що забезпечують довготривалу міцність та одночасну еластичність.
Для проведення досліджень було застосовано клеї, які використовуються при виготовленні книг у палітурці:

1. Для окантовування книжкового блоку:

- Промазка корінця книжкового блоку:

- ПВАД/15В - Україна (полівінілацетатна дисперсія), в'язкість 50-80 с;

Композиційні поєднання палітурних клеїв для виготовлення дослідних зразків

\begin{tabular}{|c|c|c|c|}
\hline № & $\begin{array}{c}\text { Клей для промазки корінця } \\
\text { книжкового блока }\end{array}$ & $\begin{array}{c}\text { Клей для бокової промазки } \\
\text { книжкового блоку }\end{array}$ & $\begin{array}{c}\text { Клей для при- } \\
\text { клейки паперо- } \\
\text { вої стрічки на } \\
\text { корінець книж- } \\
\text { кового блоку }\end{array}$ \\
\hline 1 & Термоклей Те & Термоклей & BATCH 6640 \\
\hline 2 & $\Pi \mathrm{B}$ & Термок & COL \\
\hline 3 & ПВАД/15В & Термоклей OGIMELT 110 & BATCH 6640 \\
\hline 4 & Термокле & TepN & COLGEL 630 \\
\hline 5 & Термоклей ВАМ 776 & $\begin{array}{c}\text { Термоклей } \\
\text { Technomelt Q3660 }\end{array}$ & ВАTCH 6640 \\
\hline 6 & Термоклей Technomelt Q3660 & Термоклей OGIMELT 110 & BATCH 6640 \\
\hline 7 & Термоклей Technomelt Q3660 & Термоклей OGIMELT 110 & BATCH 6640 \\
\hline 8 & Термоклей Technomelt Q3660 & OGIMELT 110 & BATCH 6640 \\
\hline 9 & Термоклей Technomelt Q3660 & Термоклей OGIMELT 110 & BATCH 6640 \\
\hline 10 & ПВАД/15В & \multirow{2}{*}{$\begin{array}{c}\text { Термоклей } \\
\text { Technomelt Q3660 }\end{array}$} & \multirow{2}{*}{ COLGEL 630} \\
\hline 11 & ПВАД/15В & & \\
\hline 12 & ПВАД/15В & Термоклей OGIMELT 110 & BATCH 6640 \\
\hline 13 & ПВАД/15В & \multirow{2}{*}{$\begin{array}{c}\text { Термоклей } \\
\text { Technomelt Q3660 }\end{array}$} & COLGEL 630 \\
\hline 14 & омоклей ВАМ & & BATCH 6640 \\
\hline 15 & Термоклей ВАМ 776 & Термоклей BAI & COLGEL 630 \\
\hline 16 & Термоклей ВАМ & СAM 849 & COLGEL 630 \\
\hline 17 & Термоклей ВАМ 776 & Термоклей ВАМ 849 & COLGEL 630 \\
\hline 18 & Термоклей ВАМ 776 & Термоклей ВАМ 849 & COLGEL 630 \\
\hline 19 & ПВА & $\begin{array}{c}\text { Термоклей } \\
\text { Technomelt Q3660 }\end{array}$ & COLGEL 630 \\
\hline 20 & Термоклей ВАМ 776 & Термоклей ВАМ 849 & COLGEL 630 \\
\hline
\end{tabular}


- Термоклей Technomelt Q3660 (Німеччина);

- Термоклей ВАМ 776 (Англія, на синтетичній основі);

- Бокова промазка книжкового блоку:

- Термоклей ВАМ 849 (Англія);

- Термоклей Technomelt Q3660 (Німеччина);

- Термоклей OGIMELT 110 (Німеччина);

2. Приклейка паперової стрічки на корінець книжкового блоку:

- COLGEL 630 (Німеччина, желатиновий клей на базі тваринних білків у формі желе середньої в'язкості);

- ВАТСН 6640 (Німеччина).

Використана для експерименту дисперсія полівінілацетату холодний дисперсійний клей 3 вмістом 50 \% твердих частинок (ПВАД). В якості захисного колоїду застосовано полівініловий спирт. Дисперсія містить від 15 \% пластифікатора. Розмір частинок становить від 0,5 до 5 мкм. Частково розбавлений $4 \%$ метилцеллюлозним клеєм.

Термоклеї, використані для експерименту: трикомпонентні системи сополімерів етиленвінілацетату. Складаються з основного полімеру, смол, що підвищують клейкість для поліпшення адгезії, пластифікаторів та жароміцних антиоксидантів.

При виготовленні книжкової продукції для проведення експериментів форматами та технічними показниками наведеними в табл. 3, використані клеї для промазки корінця блока, бокової промазки блоку і для приклейки паперової стрічки на корінець блока у позиціях наведених в табл. 2.
Експериментальні вимірювання природних кутів розкривання книжкових блоків проводилися при розкриванні блоку посередині без додаткових зусиль, направлених на деформацію корінцевої частини з метою отримання кутів розкривання наближених до 180 .

Враховуючи комплексні фактори виготовлення експериментальних зразків книжкової продукції різних форматів видань, використанні паперу на блоки різних сортів, різної маси, товщини аркушів, розривної довжини, а також різних сучасних палітурних клеїв у різних поєднаннях з блоками забезпечили результати наведені у табл. 3.

Аналіз отриманих результатів застосування клеїв в книжкових блоках показав, що композиція клеїв Термоклей ВАМ 776 + Термоклей ВАM 849 + клей COLGEL 630 забезпечила максимальні природні кути розкривання блоків у межах $62^{\circ}, 64^{\circ}, 69^{\circ}, 79^{\circ}, 90^{\circ}, 114^{\circ}$, що є придатними для довготривалого використання. Додаткові зусилля, що будуть направлені на розкриття блоків для комфортного читання у 150-180 призведуть до незначної деформації книжкових корінців і їх незначної руйнації.

Композиція клеїв Термоклей Technomelt Q3660 + Термоклей OGIMELT 110 + клей BATCH 6640 забезпечила посередній результат природних кутів розкривання блоку в проміжку 56-62. Деформація книжкових корінців буде суттєвою для дотримання умов задовільного читання.

Інші композиції палітурних клеїв не забезпечили задовільних результатів, природний кут 
розкривання блоків від $15^{\circ}$ до $42^{\circ}$. Для можливого задовільного читання таких блоків необхідно прикласти значні зусилля для деформації корінцевої частини блоку, що призведе до швидкого руйнування книги.

\section{Висновки}

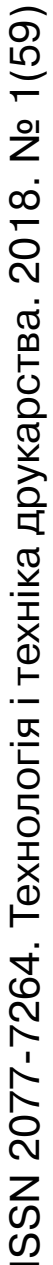

Для виготовлення книжкової продукції інтенсивного та довготривалого використання, забезпечення міцності і довговічності клейових з'єднань корінців книжкових блоків, зшитих нитками, створює підстави дотримання основних показників експлуатаційної надійності всього книжкового видання.

Аналіз проведених досліджень на утворення максимального природного кута розкривання книжкових блоків, без прикладання додаткових зусиль, направлених на деформацію корінцевої частини, виявив композиції деяких видів

Таблиця 3

Показники природних кутів розкривання книжкових блоків

\begin{tabular}{|c|c|c|c|c|c|c|c|}
\hline № & $\begin{array}{c}\text { Формат } \\
\text { видання, } \\
\text { мм }\end{array}$ & $\begin{array}{c}\text { Товщина } \\
\text { блоку, } \\
\text { мм }\end{array}$ & Папір & 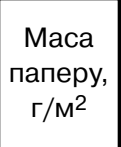 & $\begin{array}{c}\text { Товщина } \\
\text { аркуша, } \\
\text { мкм }\end{array}$ & $\begin{array}{c}\text { Розривна } \\
\text { довжина, } \\
\text { м }\end{array}$ & $\begin{array}{c}\text { Кут } \\
\text { розкри- } \\
\text { вання } \\
\text { блоку, }\end{array}$ \\
\hline 1 & $125 \times 200$ & 38 & газетний & 38 & 51 & 3298 & 56 \\
\hline 2 & $125 \times 200$ & 35 & кн-журн. & 55 & 82 & 3951 & 15 \\
\hline 3 & $128 \times 200$ & 30 & офсетний & 55 & 70 & 3314 & 15 \\
\hline 4 & $130 \times 200$ & 35 & кн-журн. & 55 & 91 & 3103 & 114 \\
\hline 5 & $195 \times 255$ & 10 & офсетний & 55 & 79 & 5842 & 42 \\
\hline 6 & $125 \times 200$ & 38 & газетний & 60 & 113 & 3000 & 56 \\
\hline 7 & $165 \times 240$ & 35 & офсетний & 65 & 122 & 3935 & 58 \\
\hline 8 & $145 \times 205$ & 50 & офсетний & 70 & 125 & 4520 & 62 \\
\hline 9 & $170 \times 240$ & 45 & офсетний & 70 & 110 & 6630 & 60 \\
\hline 10 & $200 \times 260$ & 30 & офсетний & 70 & 93 & 6057 & 44 \\
\hline 11 & $200 \times 290$ & 25 & офсетний & 70 & 75 & 3045 & 53 \\
\hline 12 & $140 \times 200$ & 40 & офсетний & 80 & 97 & 3313 & 15 \\
\hline 13 & $160 \times 235$ & 40 & офсетний & 80 & 110 & 5833 & 54 \\
\hline 14 & $165 \times 235$ & 10 & офсетний & 80 & 110 & 3850 & 39 \\
\hline 15 & $165 \times 240$ & 15 & офсетний & 80 & 110 & 5750 & 69 \\
\hline 16 & $210 \times 230$ & 15 & офсетний & 80 & 110 & 4917 & 62 \\
\hline 17 & $200 \times 290$ & 35 & офсетний & 100 & 121 & 5333 & 64 \\
\hline 18 & $210 \times 210$ & 15 & офсетний & 110 & 107 & 3187 & 79 \\
\hline 19 & $300 \times 250$ & 8 & крейдований & 120 & 90 & 3889 & 54 \\
\hline 20 & $210 \times 285$ & 8 & офсетний & 170 & 210 & 7726 & 90 \\
\hline
\end{tabular}


клеїв, що забезпечують максимальну міцність скріплення корінців і одночасну високу еластичність, що сприяє максимальному куту розкривання блоків, зшитих нит- ками і має прикладне значення при моделюванні макетів книг, виборі технології їх виготовлення та застосуванні сучасних палітурних матеріалів.

\section{Список використаної літератури}

1. Clark T. Bookbinding with adgesives. Third Edition. London, 2007.

2. Liebau D., Heinze I. Industrielle Buhbinderei, Itzehoe, 2007.

3. Воробьев Д. В. Технология брошюровочно-переплетных процессов / Д. В. Воробьев, И. А. Дубасов, Ю. М. Лебедев. М.: Книга, 1989. 392 с.

4. Кулик Л. Й. Удосконалення технології окантування корінців книжкових блоків при незшивному клейовому скріпленні: Автореф. дис. канд. техн. наук. 05.05.01. Львів: Українська академія друкарства, 2002.

5. Гавенко С. Ф. Дослідження факторів впливу на кути розкривання книжкових блоків / С. Ф. Гавенко, І. Ю. Логазяк, Л. В. Туряб // Технологія і техніка друкарства. Київ: НТУу «КПІ», 2012. Вип. 1(35). С. 67-73. Режим доступу: http://ttdruk.vpi.kpi.ua/article/view/32593.

6. Г. Петриашвили. Математическая модель напряженно-деформированого состояния клеевого соединения книжного блока / Г. Петриашвили // Поліграфія і видавнича справа. 2007. Вип. 1. С. 181-185.

7. Гавенко С. Конструкція книги / С. Гавенко, Л. Кулік, М. Мартинюк. Львів: Фенікс, 1999. 136 с.

8. Лазаренко Е. Т. Поліграфічні матеріали / Е. Т. Лазаренко, Ю. Ц. Жидецький, Н. Д. Лотошинська. Львів: Афіша, 2000.

9. Мартинюк М. С. Дослідження технологічних та експлуатаційних властивостей палітурних матеріалів / М. С. Мартинюк // Наукові записки. Львів: УАД, 1998. Вип. 1. С. 40-42.

10. ГОСТ 30435-96. Определение жесткости при изгибе статическими методоми. Бумага и картон. Межгосударственный стандарт. Минск, 2001.

11. СОУ 22.2-02477019-09:2007. Видання. Видавниче оформлення i поліграфічне виконання. Номенклатура показників якості. Київ: Держкомтелерадіо України, 2007.

\section{References}

1. Clark, T. (2007). Bookbinding with adgesives. London [in English].

2. Liebau, D. \& Heinze, I. (2007). Industrielle Buhbinderei. Itzehoe [in German].

3. Vorob'ev, D. V. \& Dubasov, I. A. \& Lebedev, Yu. M. (1989). Tekhnologiya broshyurovochno-perepletnykh protsessov. Moscow: Kniga, 392 p. [in Russian].

4. Kulyk, L. Y. (2002). Udoskonalennia tekhnolohii okantuvannia korintsiv knyzhkovykh blokiv pry nezshyvnomu kleiovomu skriplenni. Lviv: Ukrainska akademiia drukarstva [in Ukrainian].

5. Havenko, S. F. \& Lohaziak, I. Yu. \& Turiab, L. V. (2012). Doslidzhennia faktoriv vplyvu na kuty rozkryvannia knyzhkovykh blokiv. Journal of Tekhnolohiia $i$ tekhnika drukarstva, 1(35), 67-73. Retrieved from http://ttdruk.vpi.kpi.ua/article/view/32593 [in Ukrainian].

6. Petriashvili, G. (2007). Matematicheskaya model' napryazhenno-deformirovanogo sostoyaniya kleevogo soedineniya knizhnogo bloka. Journal of Polihrafiia i vydavnycha sprava, 1, 181-185 [in Russian]. 
7. Havenko, S. \& Kulik, L. \& Martyniuk, M. (1999). Konstruktsiia knyhy. Lviv: Feniks, 136 p. [in Ukrainian].

8. Lazarenko, E. T. \& Zhydetskyi, Yu. Ts. \& Lotoshynska, N. D. (2000). Polihrafichni materialy. Lviv: Afisha [in Ukrainian].

9. Martyniuk, M. S. (1998). Doslidzhennia tekhnolohichnykh ta ekspluatatsiinykh vlastyvostei paliturnykh materialiv. Journal of Naukovi zapysky, 1, 40-42 [in Ukrainian].

10. National standarts of Republic of Belarus 30435-96 (2001). Opredelenie zhestkosti pri izgibe staticheskimi metodomi. Bumaga i karton. Minsk [in Russian].

11. Standard of the Organization of Ukraine \# 22.2-02477019-09:2007 (2007). Vydannia. Vydavnyche oformlennia i polihrafichne vykonannia. Nomenklatura pokaznykiv yakosti. Kyiv: Derzhkomteleradio Ukrainy [in Ukrainian].

\section{Для изготовления книжной продукции интенсивного}

и длительного использования, обеспечение прочности и долговечности клеевых соединений корешков книжных блоков, сшитых нитками, создает основания соблюдения основных показателей эксплуатационной надежности всего книжного издания. Анализ проведенных исследований на образование максимального естественного угла раскрытия книжных блоков, без приложения дополнительных усилий, направленных на деформацию корешковой части, обнаружил композиции некоторых видов клеев, обеспечивающих максимальную прочность скрепления корешков и одновременно высокую эластичность, что способствует максимальному углу раскрытия блоков, сшитых нитками и имеет прикладное значение при моделировании макетов книг, выборе технологии их изготовления и применении современных переплетных материалов.

\section{Ключевые слова: книжные блоки; углы раскрытия; углы отклонения; прочность скрепления; переплетные клеи; разрушения блоков.}

For the production of book products of intensive and longterm use, providing durability and durability of adhesive joints of the roots of book blocks, seamed threads, creates grounds for ob-servance of the basic indicators of operational reliabi-

lity of the whole book edition. An analysis of the research carried out on the formation of the maximum natural angle of opening of the book blocks, without the application of addi- 
tional efforts directed at the deformation of the root portion, has revealed the composition of some types of adhesives that provide the maximum strength of root fixation and simultaneous

high elasticity, which contributes to the maximum angle of opening of blocks with sewn threads and has applied value, when modeling book models, selecting technology for their production and applying modern bookbinding materials.

Keywords: book blocks; opening angles; angles of deviation; strength of fastening; binder glues; destruction of blocks.

Рецензент - Ю. О. Шостачук, к.т.н., доцент, КПІ ім. Ігоря Сікорського 